\title{
Bioavailability of phosphorus of river sediments and its effect on growth of Selenastrum capricornutum
} \author{
M. van der Zee ${ }^{3}$ \\ ${ }^{1}$ Agricultural Research Education and Extension Organization \\ ${ }^{2}$ Urmia University \\ ${ }^{3}$ Wageningen University
}

Hamed Arfania ${ }^{1}$, Abbas Samadi ${ }^{2}$, Farrokh Asadzadeh $^{2}$, Ebrahim Sepehr $^{2}$, and S. E. A. T.

May 11, 2020

\begin{abstract}
Increasing anthropogenic loading of phosphorus $(\mathrm{P})$ threatens aquatic ecosystems. The bioavailability of $\mathrm{P}$ in sediments for algal growth depends on several physiochemical properties such as silt, clay, mineralogy, $\mathrm{pH}$, electrical conductivity (EC), and carbonate-content. This study was aimed on selecting the best chemical extraction method to characterize P-availability for the algae Selenastrum capricornutum. Principal component analysis (PCA) of the data identified two components that cover $79.3 \%$ of the total variation, and these components were dominated by particle size distribution, active calcium carbonate equivalence (ACCE), and EC. Many of the considered extractions were positively correlated with each other, with the exception being BrayII. The sediments of some rivers had a higher Olsen-extractable $\mathrm{P}$ than $20 \mathrm{mg} \mathrm{kg}-1$, that is considered a threshold value above which the aquatic environment may become negatively affected. The average rank order of $\mathrm{P}$ extraction by single extractants was: Colwell > Mehlich III > NaOH 0.1 M > Olsen > Morgan > AB-DTPA > Bray II. The Colwell-extractable P concentrations of sediments varied from 1.44 to $88.0 \mathrm{mg} \mathrm{kg}-1$. This extractant significantly correlated with algal growth $(\mathrm{r} 2=0.92, \mathrm{P}<0.001)$ and gave a rough estimate of the amount of bioavailable $\mathrm{P}$ in sediments. Therefore, the bioavailable content of $\mathrm{P}$ in sediments is quite high in comparison with the soils (agronomic requirement $=15 \mathrm{mg} \mathrm{P} \mathrm{kg-1)}$ ) around the Urmia Lake basin.
\end{abstract}

\section{Introduction:}

Phosphorus is a vital macronutrient that is frequently restricting primary production in rivers and lakes. In terms of the Redfield ratio (106C:16N:1P), even a small addition of P under P-limited conditions could lead to a significant growth in the primary production of aquatic ecosystems. This may lead to eutrophication and hypoxia, a water dead zone, with significant loss of biodiversity and changes in the food web (Orihel et al., 2017; Dijkstra et al., 2018). As algae may bind nitrogen, an increase in P-availability may trigger algal outbreaks. This has been observed in many cases to occur due to excessive fertilizer and manure applications

For many aquatic systems, soil and particulate-P erosion together with runoff water are main sources of inputs of P to surface water (Brendel et al., 2019). Sediment pore water and desorption from its solid phase replenish $\mathrm{P}$ in overlying waters, and become available for consumption by aquatic organisms. It has long been acknowledged that soil and sediment bound $\mathrm{P}$ is only partly biologically available to plants and aquatic organisms as algae (Van Rotterdam et al., 2012). The bioavailable fraction of $\mathrm{P}$ can be evaluated by algal bioassays (Liu et al., 2016). Although algal assays are difficult to conduct and time-consuming, the bioavailable $\mathrm{P}$ estimated by assays is considered well to quantify the potential of sediment $\mathrm{P}$ to cause eutrophication (Young et al., 1985; Ekholm and Krogerus, 2003). Indeed, the quantification of bioavailable phosphorus for algal growth was shown to be essential to estimate eutrophication risks (Ellison and Brett, 2006; Okubo et al., 2012). However, it is attractive to predict bioavailable P using a chemical measure that 
is simple, routinely applicable, and cost-efficient. A single chemical extraction that allows to screen a large number of samples and monitor the health of aquatic ecosystems requires that the relationship between bioavailability of $\mathrm{P}$ from algal bioassay experiments and chemically extracted $\mathrm{P}$ is clear and unambiguous.

A great deal of chemical extraction approaches have been evolved to estimate bioavailable P roughly in soil and sediments such as those developed by Morgan (1954), Mehlich (1983), Bray-Kurtz (1961), Colwell (1952) and Olsen et al. (1954). Chemical extractants are based on different mechanisms and abilities to extract P and may diverge from the chemical used for extraction as well as e.g. sediment: water ratio, equilibration (shaking) time, and targeted $\mathrm{P}$ pools. For instance Bray-P may be useful for acid, but not for calcareous materials. Also Mehlich-P is based on extraction by acid, but performs better for high $\mathrm{pH}$ soils. Olsen-P extracts with $\mathrm{NaHCO}_{3}$ and is more commonly used for $\mathrm{pH}$-values exceeding slightly acid values, as it was developed for alkaline soils. The well-known 0.1 M NaOH extractant is one of first methods developed to quantify algal available P (Young, 1982). Anderson and Magdoff (2005) reported that Olsen-P had the highest correlation with Selenastrum capricornutum growth in comparison with other extractants. Huettl et al, (1979) suspended sediments with hydroxy-aluminum modified cation exchange resin and detected that the $\mathrm{P}$ adsorbed onto resin had good magnitude of agreement withSelenastrum capricornutum $\left(\mathrm{r}^{2}=0.98 ; \mathrm{n}=5\right)$. The well-known 0.01M $\mathrm{CaCl}_{2}$-extraction (Boekhold et al., 1993) provided excellent results for agricultural soils that are regularly limed. Sharpley (1993) used a selective extraction that was based on establishing contact between a soil suspension and Fe-oxide coated paper strips that were developed by Van Der Zee et al. (1987). The so-called Fe-oxide paper strips significantly estimated bioavailable P from runoff sediment for P-deficient Selenastrum capricornutum(Sharpley, 1993).

Rivers are the main components of Urmia Lake ecosystems and flow in circuitous path from cities, agricultural lands, industrial area, etc., and then end up in Urmia saline lake. They are also perceived as delivering nutrient to the Lake and wetlands around it by biogeochemical processes. However, eutrophication processes are becoming dominant wetlands degradation around the Lake (Arfania et al., 2018), which is a prominent habitat of migrant birds. Soil degradation is gradually becoming the main obstacle to provide ecosystem services for irresistible Urmia Lake basin. Therefore, to develop phosphorus management and deal effectively with adverse legacy effects of sedimentary phosphorus, we investigate bioavailability of $\mathrm{P}$ for the aquatic ecosystem. To verify our argument this study was conduct to 1) develop P bioavailability assessment in sediments according to several single chemical extractions and with P-inhibited algal growth, and 2) recognize influencing factors in $\mathrm{P}$ management in sustaining aquatic life and deteriorate sediment ecosystem service.

\section{Material and Methods:}

\section{Sampling and area description}

Urmia Lake is one of the 59 international parks of world heritage designated by the United Nations. It is located between west and east Azerbaijan in the uppermost northwest center of Iran. It has coordinates between 37 to 38 degrees and 15 minutes north latitude, and between 45 to 46 degrees east longitude. The Urmia National Park consists of three units: 1) a water unit, 2) a mountain and coastal plain unit, 3) rivers and wetlands. Urmia Lake basin has an area of $51876 \mathrm{~km} 2$, which comprises $38 \%$ mountainous areas, $21 \%$ hills, $11.2 \%$ flats and terraces, $9 \%$ lakes, and the remainder (20.8\%) includes plains and various lands utilized for different uses. From 19 rivers flowing into the lake, 14 are permanent and 5 others are seasonal rivers. The annual water discharge is estimated to be 5317 million $\mathrm{m}^{3}$. The desiccation of Urmia Lake and lowering of the river water level entering the lake, illustrates the need to give attention to the increasing pollution of rivers and wetlands around the lake. Water diversion and management of dryland regions for agricultural practices are having a serious impact on the water quality in the Urmia Lake basin.

Twenty-five representative sediment samples from seven main western rivers of Urmia Lake basin were collected for this study (Figure 1). Each river was sampled from the upstream of mountainous region to downstream point river plain near discharge to Urmia Lake, and sometimes in-between. The vertical sediment cores $(0-10 \mathrm{~cm})$ was collected from each sampling site and then mixed to have a composite sample. For the Urmia Lake basin, water levels rise and overland flow occurs seasonally in the riverbed sediments, therefore 
most sediment samples were selected from summer during the reduction of river flow.

\title{
Characterization of the sediment
}

Before starting any experiment all sediment samples was air-dried at room temperature and ground with pestle and mortar to put sediment through stainless steel 10 mesh sieve. The sediments physical composition including clay and silt contents were determined by hydrometer method and then sand and very find sand (Vfs) were weighed after washing over sieve and $110 \mathrm{C}$ oven drying. Organic matter (OM) content was determined with the classical Walkley-Balck procedure (Rowell, 1994). The activity of $\mathrm{H}_{3} \mathrm{O}^{+}, \mathrm{pH}=[-\mathrm{log}$ $\left(\mathrm{H}^{+}\right)$] and conductivity (EC) were measured in a sediment-solution ratio of 1:5. The acid-base titration method was used for determination of calcium carbonate equivalents (CCE) (Rowell, 1994). The activity of calcium carbonate (ACCE) was measured in ground uniform sediment particles with ammonium oxalate method (Loeppert and Suarez, 1996).

Sediments were extracted using several single extraction methods that are summarized in Table 1 . Olsen-P and Colwell-P extraction method have been designed for calcareous soils. Mehlich III-P and Bary II-P have been designed for acidic soil, and both contain $\mathrm{HCl}$ acid and ammonium fluoride for dissolution of Fe/Al-P minerals such as Strengite, $\left(\mathrm{FePO}_{4} \cdot 2 \mathrm{H}_{2} \mathrm{O}\right)$ and Variscite, $\left(\mathrm{AlPO}_{4} \cdot 2 \mathrm{H}_{2} \mathrm{O}\right)$. AB-DTPA extraction method is chelating agent for $\mathrm{Fe}, \mathrm{Al}, \mathrm{Ca}$, and $\mathrm{Mg}$ and has been shown to be a good extraction method for acidic and calcareous soils. Morgan-P was designed for soil with a high association of Ca-P pools and usually dissolve soluble calcium phosphate (Ahmad and Jones, 1967). 0.1 M NaOH is for soil and sediment with high Fe/Al-P pools. Chemical analysis of $\mathrm{P}$ was done colorimetrically (Murphy and Riley, 1962).

\begin{tabular}{lll}
\hline Table 1- Used phosphorus extraction methods & Table 1- Used phosphorus extraction methods & Table 1- Used phosphorus \\
\hline Reference & Reference & Sediment: Water \\
Olsen et al (1954) & Olsen et al (1954) & $1: 20$ \\
Colwell (1963) & Colwell (1963) & $1: 50$ \\
Mehlich (1984) & Mehlich (1984) & $1: 10$ \\
Morgan (1941) & Morgan (1941) & $1: 10$ \\
Bray and Kurtz (1954) & Bray and Kurtz (1954) $1: 10$ \\
Soltanpour and Schwab (1977) & Soltanpour and Schwab (1977) & $1: 20$ \\
Sharpley (1991) & Sharpley (1991) & $1: 100$ \\
\hline
\end{tabular}

\begin{abstract}
Algal Bioassay
Selenastrum capricornutum , (a coccoid unicellular green algae) was cultivated in a nutrient stock solution containing macronutrients NaNO3, $\mathrm{MgCl}_{2} \cdot 6 \mathrm{H}_{2} \mathrm{O}, \mathrm{CaCl}_{2} .2 \mathrm{H}_{2} \mathrm{O}, \mathrm{MgSO}_{4} .7 \mathrm{H}_{2} \mathrm{O}$, and $\mathrm{K}_{2} \mathrm{HPO}$ (25.5, 12.2 , 4.41, 14.7 and $1.04 \mathrm{mg} \mathrm{L}^{-1}$, respectively), and micronutrients: $\mathrm{H} 3 \mathrm{BO} 3, \mathrm{MnCl}_{2} .4 \mathrm{H}_{2} \mathrm{O}, \mathrm{ZnCl}_{2}, \mathrm{CoCl}_{2} .6 \mathrm{H}_{2} \mathrm{O}$, $\mathrm{CuCl}_{2} \cdot 2 \mathrm{H}_{2} \mathrm{O}, \mathrm{Na}_{2} \mathrm{MoO} 4.2 \mathrm{H} 2 \mathrm{O}, \mathrm{FeCl}_{3} \cdot 6 \mathrm{H}_{2} \mathrm{O}$, and $\mathrm{Na}_{2} \mathrm{SeO} 4$ (185 416, 3.27, 1.43, 0.012, $7.26,160$ and $2.39 \mu \mathrm{g}$ $\mathrm{L}^{-1}$, respectively). Light source intensity was $250 \mu \mathrm{M} \mathrm{m}^{-2} \mathrm{~s}^{-1}$ of photosynthetically active radiation (PAR). Temperature was kept at $21^{\circ} \mathrm{C}$ during the day. The culture medium was aerated and disturbed twice daily by hand until cells reached a stationary growth phase $(10 \mathrm{~d})$. To improve test performance $\mathrm{Na}_{2} \mathrm{EDTA}_{2} 2 \mathrm{H}_{2} \mathrm{O}$ $300 \mu \mathrm{g} \mathrm{L} \mathrm{L}^{-1}$ was added. The medium was buffered with NaHCO3 $15 \mathrm{mg} \mathrm{\textrm {L } ^ { - 1 }}$. At the stationary phase, the medium was centrifuged at $3000 \mathrm{~g}$, supernatant was discarded and pellets introduced to P-free nutrient growth medium. When the algae cells started to turn yellow (about 7 days), additional three days were allowed for ensuring that the medium was suffered from starvation (Figure. 2).

There were three replicates for each sediment suspension by adding $100 \mathrm{mg}$ of sediment to $50 \mathrm{~mL}$ of $\mathrm{P}$ free nutrient culture medium. The suspension was autoclaved at $121^{\mathrm{O}} \mathrm{C}$ and 15 psi to avoid microbial contaminations. The algal bioassay commenced when the P-starved algae was added to the test flask (250 $\mathrm{mL}$ erlnmeyer). The suspension of sediment and P-free medium was inoculated by Selenastrum capricornutum faced with $\mathrm{P}$ starvation to bring an initial flasks concentration to $3 \times 104$ cell $\mathrm{mL}^{-1}$. The the cotton-stoppered flasks were incubated at a constant temperature and light intensity (see above) and stirred manually twice
\end{abstract}


a day to minimize possible spatial variability in light radiation. Cell counting was carried out using a hemocytometer counting chamber at the end of experiment.

\section{Statistical Analysis}

A wide range of statistical analyses were performed with Minitab 16. From simple Pearson correlations to multivariate analysis such as principal component analysis (PCA) and cluster analysis to separate prominent features from variables and observation.

\section{Results}

\section{Sediment properties and analysis}

The variation of sediment chemical and physical characteristics was depicted in the figure 3 . Sand and clay contents of sediments showed large variations in comparison with silt. The average EC of sediments was $0.42 \mathrm{dS} \mathrm{m}^{-1}$ suggesting that the water quality of rivers is appropriate. The OM content of sediments was significantly different, and varied from 0.56 to 5.56 with average of 1.76 . The average percent CCE and ACCE of sediments were 15.03 (2.50-23.75) and 2.08 (0.54-3.86), respectively (figure. 3).

To recognize the physico-chemical properties and sediment that controls the variability of the data, the provided diagram shows the results of a principal component analysis (PCA) of sediment characteristic variables (figure 4). The first and second components together represent $79.3 \%$ of the variation. First PC is mainly determined by ACCE, clay, and silt, and is negatively dependent on Vfs, D50 and Sand. This implies that correlated variables control variation in the data set. The second component showed strong negative correlations with $\mathrm{pH}$ and $\mathrm{CCE}$, negatively correlated with OM, and EC. There were large differences between observations from various samples (Figure 4).

\section{Relationships between various sediment $\mathbf{P}$ extractants}

Although there were large variations between the P-extractants, they were significantly correlated with each other with $\mathrm{r}^{2}$ values ranging from 0.68 to 0.95 . As is observed, the figure of cluster analyses in the seven mentioned extractants no overall pattern of distance rather show the noticeable similarity from extractant to extractant (figure 5). Generally speaking, it seems that the four extractants (Colwell, Mehlich III, Olsen, and Morgan) extract P from equally the same pools and strong correspondingly is between Mehlich III and Olsen. Among the all extractants, $0.1 \mathrm{M} \mathrm{NaOH}$ showed quite different behavior and separated itself in a group (figure 5).

\section{Algal growth and sediment test phosphorus}

The line graph gives relationship between algal growth and seven above-mentioned $\mathrm{P}$ tests (Figure 6), which reflects that algal growth altered in the incubation period from sediments. There was a highly significant correlation between EC and Selenastrum capricornutumpopulations $\left(\mathrm{r}^{2}=0.87\right)$ (Figure 7). This implies that the sediments with high salinity supply enough $\mathrm{P}$ for the growth of the algae. Overall, the $\mathrm{pH}$ and CCE had decayed the algal growth. Pearson's correlations were performed to investigate the relationship between $\mathrm{P}$ extraction efficiency and sediment physico-chemical properties. Obviously, the correlation factor was higher for Colwell than other P extractants for EC $(\mathrm{r}=0.93, \mathrm{P}<0.001)$

\section{Discussion:}

The interquartile range (Q3-Q1) for the OM was limited and equal to $1.15 \%$. The difference between the interquartile range and the range of data along with box plot of data revealed that some river sediments had $\mathrm{OM}>2.5$ content (figure 3). These values are higher than background OM content of soils in the upland area and agricultural soil around the Urmia Lake basin. It seems that organic matter enrichment in parallel with anthropogenic activity in one hand, and preferential soil OM erosion and degradation in upland area due to lower density of OM in other, are the main reason to this variations. By and large, the reaction of sediments was alkaline, which might be related to higher CCE in carbonate-rich rocks erosion in the basin 
and ACCE which may probably be due to biogenic carbonate genesis in the aquatic conditions of Urmia Lake 's river.

Overall, the PCA analysis revealed that variation of sediments properties is dominated by particle size distribution, and to a slightly smaller extent by EC, ACCE and OM. Particle size distribution varied, which was partly due to differences of geomorphological features of rivers, slope of terrain, and geological structure of region. It seems that higher CCE contents in the sediment reduced the fluctuation of $\mathrm{pH}$ in the studied sediments; however, the negative correlation OM and EC can reduce this fluctuation.

Downstream sediments had a higher Olsen-extractable $\mathrm{P}$ than the threshold amount of $20 \mathrm{mg} \mathrm{kg}{ }^{-1}$, indicating possible release that may adversely affect the aquatic environments (McDowell et al., 2001; Sims et al., 2002). The strongest similarity is observed between sediment Mehlich III-P and Olsen-P (figure 8). Considering that the $\mathrm{pH}$ of most sediments in this study was less than 7.6 and negative effect $\mathrm{CaCO}_{3}$ on $\mathrm{P}$ extraction, perhaps Mehlich III might tend to be less effective in higher $\mathrm{CaCO}_{3}$ contents on the $\mathrm{P}$ extracting solution (Kuo, 1996; Wang et al., 2015). In Mehlich III, the extraction with nitric acid, and acetic acid, lead to the dissolution of $\mathrm{P}$ precipitates from sediment by the generation of complexes with iron and aluminum and calcium. As fluoride and calcium form precipitates of calcium fluoride, this leads to dissolution of calcium phosphates (Kamprath and Watson, 1980). The weakest correlation was found between sediment Olsen- P and Bray-II-P, likely due to small extraction by the Bray-II P test for sediments with $\mathrm{pH}>7$ or sediments with a high degree of base saturation (Sims, 2000). However, the lack of correlation between Mehlich III and Bray II was not expected, because there is a common belief that these two methods extract similar P pools from soils and sediments by cation hydrolysis (Kleinman et al., 2001; Ebeling et al., 2008; Wang et al., 2016). We attribute the poor correlation between these two methods was to the high $\mathrm{pH}$ of some sediment samples $(\mathrm{pH}>7.3)$ (Sotomayor-Ramírez et al., 2004) and a range of sediment P levels studied with Mehlich III-P $<50 \mathrm{mg} \mathrm{kg}{ }^{-1}$. There was a significant positive correlation between all $\mathrm{P}$ extractions except with Bray II and Total-P contents. Zhou et al. (2001) expressed a good correlation between extracted Total-P with Olsen-P and $0.1 \mathrm{M} \mathrm{NaOH}$. However, cluster analysis showed that similarity between $\mathrm{NaOH} 0.1 \mathrm{M}$ and Total-P in sediments was weaker than those of other extractants.

Overall, the widespread distance among the P-extractant may attributable to contribution of $\mathrm{P}$ pools with various release potential. Despite the fact that AB-DTPA had lowest rank order of P extraction after BrayII, it had strange coincidence with Total-P in the processes of removing $\mathrm{P}$, indicating that the AB-DTPAextracted $\mathrm{P}$ might not be in favor of exclusive $\mathrm{P}$ pools (figure 5). Therefore, to develop comprehensive $\mathrm{P}$ sediment testing between terrestrial and aquatic ecosystems, we need to be mindful of contribution different $\mathrm{P}$ pools in eutrophication and properties of sediment governing the $\mathrm{P}$ bioavailability in aquatic ecosystems.

Of the seven sediment $\mathrm{P}$ test measurements, Colwell-P correlated best with algal growth $\left(\mathrm{r}^{2}=0.92, P<0.001\right)$. One of the important reasons for the high correlation between Colwell-P and Olsen-P with algal growth is that the $\mathrm{pH}$ of $S$. capricornutum growth medium, buffered against $\mathrm{pH}$ fluctuation with $\mathrm{NaHCO}_{3}$ at 7.5 , was much nearer chemically to the Olsen and Colwell extracts of $0.5 \mathrm{M} \mathrm{NaHCO}_{3}$ at $\mathrm{pH} 8.5$ than the other extractants. The solid : solution ratio (1:50) and the long extraction time of Colwell-P are more similar to the S. capricornutum growth conditions (1:100), which is the plausible reason that it outperformed the Olsen-P (1:20) extraction. McDowell et al (2020) predicted that for sedimentary soil P sorption strength or capacity is low, and it takes shortest time to reach the agronomic target $20 \mathrm{mg} \mathrm{L}^{-1}$.

Similarly, 0.1 M NaOH had a significant relationship with algal growth. Phosphorus associated with Fe/Al-P minerals or adsorbed onto $\mathrm{Fe}$ and $\mathrm{Al}$ oxides which can be dissolved and exchanged with $\mathrm{OH}^{-}$and soluble in bases (Wu et al., 2011). Dorich et al. (1984) also found that 0.1 M NaOH-extractable phosphorus was significantly correlated with 2-day and 14-day available phosphorus for an alga (S. capricornutum ). The high correlation between $0.1 \mathrm{M} \mathrm{NaOH}$ and algal growth indicated the sensitivity of $\mathrm{P}$ bioavailability to redox conditions in river system.

Morgan-P (NaActate $\mathrm{pH}=4.8$ ) was expected to extract $\mathrm{P}$ from Ca-P pools bound to the authigenic carbonate fluorapatite (CFAP) + biogenic apatite (Ruttenberg, 1992). The correlation between Morgan-P and algal 
growth was therefore significant. In fact, the presence of $\mathrm{CaCO}_{3}$ as a controlling solid of the activity of $\mathrm{Ca}^{2+}$ in solution is a plausible reason for lower $\mathrm{P}$ mobility in aquatic environment rather than that of carbonate anions, that affects $\mathrm{P}$ transfer in leaching column (Jalali and Jalali., 2107). Torbert et al. (2002) studied relationship of soil depth and phosphorus runoff losses in calcareous and non-calcareous soils. They denoted that $\mathrm{P}$ losses by runoff in calcareous soil was decreased because of the reaction of $\mathrm{Ca}^{2+}$ with orthophosphate to form insoluble Ca-P minerals. William et al. (1980) reported that absorption of P byScenedesmus quadricauda differed from 8 to $50 \%$ of total $\mathrm{P}$ and from 38 to $83 \%$ of nonapatite inorganic $\mathrm{P}$ when measured directly. The assimilation of $\mathrm{P}$ from Ca-P pool by Microcystis aeruginosa has been reported under sediment resuspension condition (Xiao-Fei et al, 2015).

Overall, bioavailable-P measurements were consistently high in sediments with high total-P concentrations, however, in some sediments with low Total-P content, the response was very high during the two-week growth period and even continued for a long period of time. A mechanistic explanation tells us that the presence of internal conversion of $\mathrm{P}$ from recalcitrant $\mathrm{P}$ pool to bioavailable $\mathrm{P}$ is another reason for occurring eutrophic condition in river system. The Colwell extractant separated sediments well against the algal population. It means that sediments with high bioavailable $\mathrm{P}$ had high algal growth. Some sediment $\mathrm{P}$ can be easily desorbed and released, particularly when the $\mathrm{P}$ is depleted from water column. It is expected that Colwellextracted $\mathrm{P}$ would separate from potentially to immediately available $\mathrm{P}$ in natural condition. Therefore, the drop in water quality is common phenomenon even in sediments below the threshold values. The proportion of Colwell-P to Total-P in the sediments of rivers was the most consistent of all the extractions used.

The sediment of the present investigation had an EC of only 0.23 to $1.22 \mathrm{dS} \mathrm{m}^{-1}$ and our data suggest that an increasing EC might lead to larger P bioavailability and eutrophication (figure 7). This larger growth could be related with greater ionic pair's formation of orthophosphate, but it might also be due to other factors such pollution entering the river system. Several earlier studies also showed a rise in P bioavailability with increasing salinity (Jordan et al., 2008; Hartzell et al., 2010; Li et al., 2015); however, this salinity is in the threshold that does not hinder organism survival $(\mathrm{EC}=0.46 \pm 0.28)$. From the negative relationship between algae growth and both $\mathrm{CCE}$ and $\mathrm{pH}$ could be deduced that these sediment properties restricted the degree of eutrophication (Figure 5). Therefore, Selenastrum capricornutum is not calcium-loving and occurs in calcareous streams with deposits of travertine and tufa. Drylie et al (2019) reported that $\mathrm{CaCO}_{3}$ dampened the effects of eutrophication-induced acidification and OM enrichment in the costal sediments. There is also a positive relationship between $\mathrm{OM}$ and the algae growth, which might represent the availability of organic $\mathrm{P}$ for the growth of algae thus decreasing resilience of river system by creating hypoxic condition in water (Kortinger et al., 2001)

The $\mathrm{P}$ extractants were negatively correlated with $\mathrm{pH}$ and the correlation was strongest with $0.1 \mathrm{M} \mathrm{NaOH}$. Wang et al. (2012) concluded that soil $\mathrm{pH}$ was master variable in estimating $\mathrm{P}$ mobility and leaching by single P extraction indicators. The study by Arfania et al. (2018) revealed that sediment chemical properties such as electrical conductivity, organic matter, $\mathrm{pH}$ and calcium carbonate, had effects on the distribution and bioavailability of $\mathrm{P}$ pools. Calcium carbonate equivalence (CCE) was negatively correlated with Colwell and $\mathrm{NaOH}$ 0.1 M. Olsen, Colwell and $0.1 \mathrm{M} \mathrm{NaOH}$ extractant were positively correlated with organic matter content Jalali and Jalali. (2017) reported that $\mathrm{pH}$, and EC made important contributions to most P release from leaching column, while $\mathrm{OM}$ and silt content was less contributed on $\mathrm{P}$ availability. A positive correlation of Olsen and Mehlich III with the silt fraction signified the influence of sediment particle size on P bioavailability.

\section{Conclusion:}

Due to population growth and the associated agricultural developments and upland soil erosion, western rivers discharging in Urmia Lake release massive quantities of P-loaded water and sediment. This is the main reason for eutrophication of wetlands at this lake. In this investigation, a selection of extraction methods was considered in their capability to extract sediment-bound P. The extracted quantities appeared to vary significantly between these methods, even though most methods showed a good correlation with each other. The extracted $\mathrm{P}$ was also compared with algae growth in a bio-assay, for the algaeSelenastrum capricornu- 
tum . Correlations with algal growth were modest, except for the Colwell-P that correlated very well. For sediments as discharged into Urmia Lake, where $\mathrm{pH}$ and EC appears to have an effect on algae growth, the Colwell-P extraction therefore looks as the best option. Because of dense algal bloom in lower research areas, withholding fertilizer application for building up crop requirement is recommended in susceptible land for erosion.

\section{References:}

Ahmad, N., Jones, R.L., 1967. Forms of occurrence of inorganic phosphorus and its chemical availability in the limestone soils of Barbados. Soil Sci. Soc. Am. J. 31(2), 184-188. doi:10.2136/sssaj1967.03615995003100020013x

Anderson, B.H., Magdoff, F.R., 2005. Autoclaving soil samples affects algal-available phosphorus. J. Environ Qual. 34(6), 1958-1963. doi:10.2134/jeq2005.0024

Arfania, H., Samadi, A., Asadzadeh, F., Sepehr, E., Jaisi, D., 2018. Distribution of phosphorus pools in western river sediments of the Urmia Lake basin, Iran. Environ Sci. Pollut Res. 25(12), 11614-11625. https://doi.org/10.1007/s11356-018-1191-3

Boekhold, A.E., Temminghoff, E.J.M., Van der Zee, S.E.A.T.M., 1993. Influence of electrolyte composition and $\mathrm{pH}$ on cadmium sorption by an acid sandy soil. J Soil Sci. 44(1), 85-96. https://doi.org/10.1111/j.13652389.1993.tb00436.x

Bray, R.H., Kurtz, L.T. 1945. Determination of total, organic, and available forms of phosphorus in soils. Soil Sci. 59(1), 39-46. http://dx.doi.org/10.1097/00010694-194501000-00006

Brendel, C.H., Soupir, M.L., Long, L.A.M., Helmers, M.J., Charles D. Ikenberry C.D., Kaleita, A.L. 2019. Catchment-scale Phosphorus Export through Surface and Drainage Pathways. J. Environ. Qual. 48:117-126. doi:10.2134/jeq2018.07.0265

Colwell, J.D., 1963. The estimation of the phosphorus fertilizer requirements of wheat in southern New South Wales by soil analysis. Aust. J. Exp Agri. 3(10),190-197. https://doi.org/10.1071/EA9630190

Drylie, T.P. Needham, H.R. Lohrer, A.M., Hartland, A., Pilditch, C.A. 2019. Calcium carbonate alters the functional response of coastal sediments to eutrophication-induced acidification. Scientific Reports. 9,12012.

Dijkstra, N., Kraal, P., Séguret, M.J.M., Flores, M.R., Gonzalez, S., Rijkenberg, M.J., Slomp, C.P., 2018. Phosphorus dynamics in and below the redoxcline in the Black Sea and implications for phosphorus burial. Geochim Cosmo Acta. 222, 685-703. https://doi.org/10.1016/j.gca.2017.11.016

Dorich, R.A., Nelson, D.W., Sommers, L.E., 1984. Availability of phosphorus to algae from eroded soil fractions. Agric. Ecosyst. Environ. 11(3), 253-264. https://doi.org/10.1016/0167-8809(84)90034-3

Ekholm, P., Krogerus, K., 2003. Determining algal-available phosphorus of differing origin: routine phosphorus analyses versus algal assays. Hydrobiologia. 492(1-3), 29-42. https://doi.org/10.1023/A:1024857626784

Ellison, M.E., Brett, M.T., 2006. Particulate phosphorus bioavailability as a function of stream flow and land cover. Water Res. 40(6), 1258-1268. https://doi.org/10.1016/j.watres.2006.01.016

Hartzell, J.L., Jordan, T.E., Cornwell, J.C., 2010. Phosphorus burial in sediments along the salinity gradient of the Patuxent River, a subestuary of the Chesapeake Bay (USA). Estuaries Coasts. 33(1), 92-106. https://doi.org/10.1007/s12237-009-9232-2

Huettl, P.J., Wendt, R.C., Corey, R.B., 1979. Prediction of Algal-Available Phosphorus in Runoff Suspensions. J Environ Qual. 8(1), 130-132. https://doi.org/10.2134/jeq1979.00472425000800010028x

Jalali, M., Jalali, M., 2016. Relation between various soil phosphorus extraction methods and sorption parameters in calcareous soils with different texture. Sci Total Environ. 566, 1080-1093. https://doi.org/10.1016/j.scitotenv.2016.05.133 
Loeppert R.H., Suarez D.L., 1996. Carbonate and Gypsum, in: Sparks, D.L., Page, A.L., Helmke, P.A., Loeppert, P.N., Tabatabai, M.A., Johnston, C.T., Summers, M.E. (Eds.), Methods of Soil Analysis. Part 3. Chemical Methods. SSSA, NO.5, Madison, pp. 437-474.

Kamprath, E.J., Watson, M.E., 1980. Conventional soil and tissue tests for assessing the phosphorus status of soils. The role of phosphorus in agriculture, pp, 433-469. https://doi.org/10.2134/1980.roleofphosphorus.c17

Kortzinger, A., Hedges, J.I., Quay, P.D. 2001. Redfield ratios revisited: Removing the biasing effect of anthropogenic CO2. Limnol. Oceanogr. 46: 967-970. https://doi.org/ 10.4319/lo.2001.46.4.0964

Kuo, S., 1996. Phosphorus. In: Sparks, D.L. (Ed.),Methods of Soil Analysis. Part 3. Chemical Methods SSSA Book Ser. 5. SSSA, Madison, WI, pp. 869-919.

Li, W., Joshi, S.R., Hou, G., Burdige, D.J., Sparks, D.L., Jaisi, D.P., 2015. Characterizing phosphorus speciation of Chesapeake Bay sediments using chemical extraction, 31P NMR, and X-ray absorption fine structure spectroscopy. Environ. Sci. Technol. 49(1), 203-211. https://doi.org/10.1021/es504648d

Liu, J., Luo, X., Zhang, N., Wu, Y., 2016. Phosphorus released from sediment of Dianchi Lake and its effect on growth of Microcystis aeruginosa. Environ. Sci. Pollut. Res. 23(16), 16321-16328. https://doi.org/10.1007/s11356-016-6816-9

McDowell, R., Sharpley, A., Brookes, P., Poulton, P., 2001. Relationship between soil test phosphorus and phosphorus release to solution. Soil Sci. 166(2), 137-149. https://doi.org/10.1097/00010694-200102000-00007

McDowell, R., Dodd, R., Pletnyakov, P., Noble, A. 2020. The ability to reduce soil legacy phosphorus at a country scale. Front. Envrion. Sci. 8:6. https://doi.org/ 10.3389/fenvs.2020.00006

Mehlich, A., 1984. Mehlich 3 soil test extractant: A modification of Mehlich 2 extractant. Commun Soil Sci Plant Anal. 15(12), 1409-1416. https://doi.org/10.1080/00103628409367568

Morgan, M.F., 1941. Chemical soil diagnosis by universal soil testing. Bull. 450. Connecticut Agricultural Experiment Station. New Haven.

Murphy, J.A.M.E.S., Riley, J.P., 1962. A modified single solution method for the determination of phosphate in natural waters. Anal chim acta. 27, 31-36. https://doi.org/10.1016/S0003-2670(00)88444-5

Okubo, Y., Inoue, T., Yokota, K., 2012. Estimating bioavailability of soil particulate phosphorus to Microcystis aeruginosa. J. Appl Phycol. 24(6), 1503-1507. https://doi.org/10.1007/s10811-012-9809-1

Olsen, S. R., C. V. Cole, F. S. Watanabe., L. A. Dean. 1954. Estimation of available phosphorus in soils by extraction with sodium bicarbonate. USDA, Cire. 939, U. S. Gover. Prin. Office, Washington DC.

Orihel, D.M., Baulch, H.M., Casson, N.J., North, R.L., Parsons, C.T., Seckar, D.C., Venkiteswaran, J.J., 2017. Internal phosphorus loading in Canadian fresh waters: a critical review and data analysis. Can. J. Fish. Aquat. Sci. 74(12), 2005-2029. https://doi.org/10.1139/cjfas-2016-0500

Rowell, D.L., 1994. Soil science: methods and application, part 7: Measurement of the composition of soil solution.

Ruttenberg, K.C., 1992. Development of a sequential extraction method for different forms of phosphorus in marine sediments. Limnol Oceanogr. 37(7), 1460-1482. https://doi.org/10.4319/lo.1992.37.7.1460

Sharpley, A.N., 1993. An innovative approach to estimate bioavailable phosphorus in agricultural runoff using iron oxide-impregnated paper. J. Environ. Qual. 22(3), 597-601. https://doi.org/10.2134/jeq1993.00472425002200030026x

Sims, J.T., 2000. Soil test phosphorus: Mehlich 3. In: Pierzynski, G.M. (Ed.), Methods of Phosphorus Analysis for Soils, Sediments, Residuals, and Waters Southern Cooperative Series Bulletin no. 396. North Carolina State University, pp. 17-19. 
Sims, J.T., Maguire, R.O., Leytem, A.B., Gartley, K.L., Pautler, M.C., 2002. Evaluation of Mehlich 3 as an agri-environmental soil phosphorus test for the Mid-Atlantic United States of America. Soil Sci. Soc. Am. J. 66(6), 2016-2032. https://doi.org/10.2136/sssaj2002.2016

Soltanpour, P.A., Schwab, A.P., 1977. A new soil test for simultaneous extraction of macroand micro-nutrients in alkaline soils. Commun. Soil. Sci. Plant Anal. 8(3),195-207. https://doi.org/10.1080/00103627709366714

Sotomayor-Ramirez, D., Martinez, G.A., Mylavarapu, R.S., Santana, O., and Guzman, J.L., 2004. Phosphorus soil tests for environmental assessment in subtropical soils. Commun. Soil. Science. Plant Anal. 35(11-12), 1485-1503. https://doi.org/10.1081/CSS-120038550

Torbert, H.A., Daniel, T.C., Lemunyon, J.L., Jones, R.M., 2002. Relationship of soil test phosphorus and sampling depth to runoff phosphorus in calcareous and noncalcareous soils. J. Environ. Qual. 31(4), 13801387. https://doi.org/10.2134/jeq2002.1380

USEPA, 1986. Quality Criteria for Water. USEPA Report 440/5-86-001. Office of Water Regulations and Standards, Washington, DC.

Van der Zee, S.E.A.T.M., Fokkink, L.G.J., van Riemsdijk, W.H., 1987. A new technique for assessment of reversibly adsorbed phosphate, Soil Sci. Soc. Am. J. 51, 599-604. https://doi.org/10.2136/sssaj1987.03615995005100030009x

Van Rotterdam, A.M.D., Bussink, D.W., Temminghoff, E.J.M. and Van Riemsdijk, W.H., 2012. Predicting the potential of soils to supply phosphorus by integrating soil chemical processes and standard soil tests. Geoderma. 189, 617-626. https://doi.org/10.1016/j.geoderma.2012.07.003

Wang, Y.T., Zhang, T.Q., O'Halloran, I.P., Tan, C.S., Hu, Q.C., Reid, D.K., 2012. Soil tests as risk indicators for leaching of dissolved phosphorus from agricultural soils in Ontario. Soil Sci. Soc. Am. J. 76(1), 220-229. https://doi.org/10.2136/sssaj2011.0175

Wang, Y.T., Zhang, T.Q., O'Halloran, I.P., Hu, Q.C., Tan, C.S., Speranzini, D., Macdonald, I., Patterson, G., 2015. Agronomic and environmental soil phosphorus tests for predicting potential phosphorus loss from Ontario soils. Geoderma. 241, 51-58. https://doi.org/10.1016/j.geoderma.2014.11.001

Williams, J.D.H., Shear, H., Thomas, R.L., 1980. Availability to Scenedesmus quadricauda of different forms of phosphorus in sedimentary materials from the Great Lakes1. Limnol Oceanogr. 25(1),1-11. https://doi.org/10.4319/lo.1980.25.1.0001

Xiao-Fei, W., Da-Peng, L., Ming, W., Ren, W., 2015. Bioavailability of sedimentary phosphorus under repeated sediment resuspension with the addition of algae. Environm Sci. Pollut Res. 22(17), 13004-13013. https://doi.org/10.1007/s11356-015-4554-z

Young T. C. 1982. Algal-availability of particulate phosphorus from diffuse and point sources in the lower Great Lakes basin. Hydrobiologia. 91:111-119. https://doi.org/10.1007/BF02391926

Young, T.C., DePinto, J.V., Martin, S.C., Bonner, J.S., 1985. Algal-available particulate phosphorus in the Great Lakes Basin. J. Great Lakes Res. 11(4), 434-446. https://doi.org/10.1016/S0380-1330(85)71788-1

Zalba, P., Galantini, J.A., 2007. Modified Soil-Test Methods for Extractable Phosphorus in Acidic, Neutral, and Alkaline Soils. Commun. Soil. Sci. Plant Anal. 38(11-12),1579-1587. https://doi.org/10.1080/00103620701378508

Zhou, Q., Gibson, C.E., Zhu, Y., 2001. Evaluation of phosphorus bioavailability in sediments of three contrasting lakes in China and the UK. Chemosphere. 42(2), 221-225. https://doi.org/10.1016/S0045$6535(00) 00129-6$ 


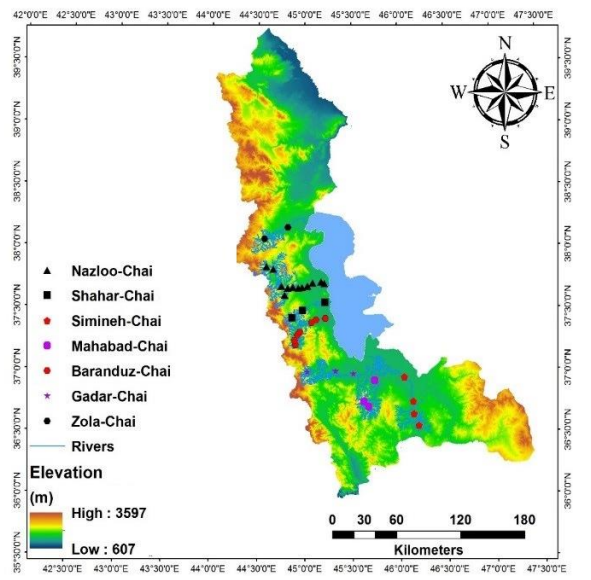

Figure 1. Study area showing location of sampling sites in western rivers in the Urmia Lake basin

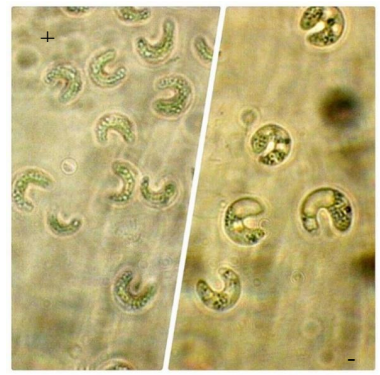

Figure 2. Magnification of (Selenastrum capricornutum) under microscope. Symbols $+\mathrm{P}$ (left)

\section{Hosted file}

Figures.pdf available at https://authorea.com/users/308200/articles/450120-bioavailabilityof-phosphorus-of-river-sediments-and-its-effect-on-growth-of-selenastrum-capricornutum 